\title{
TEMER E OS MEMES: A NORMA CULTA NA ORALIDADE DO PRESIDENTE E AS REPERCUSSÕES EM COMENTÁRIOS NA INTERNET
}

\author{
TEMER AND THE MEMES: THE \\ STANDARD CULTS IN THE ORALITY \\ OF THE PRESIDENTAND THE \\ REPERCUSSIONS IN COMMENTS ON \\ THE INTERNET
}

\author{
Mariano Jeferson Teixeira* \\ $U E P G$ \\ Valeska Gracioso Carlos** \\ UEPG
}

Resumo: Análises bibliográficas e leituras de textos publicados na internet, que configuram uma discussão sobre o uso da linguagem oral rebuscada do presidente Michel Temer, levaram à produção deste artigo, cujo objetivo é discutir como a internet, por meio dos chamados memes, tem favorecido as reações de internautas em redes sociais em relação ao novo cenário político brasileiro. As discussões aqui propostas estão fomentadas por teóricos como Britto (2002), Correa (2014) Faraco (2008) e Ferreira (2010) entre outros que argumentam sobre as políticas linguísticas, identidades e ideologias, as quais muitas vezes revelam valores de verdade ou prestígio. Com o estudo constatou-se que a internet tem possibilitado à população participar, opinar e debater sobre temas diversos, e os memes configuram uma ferramenta eficaz de reação e opinião nas páginas das redes sociais. Por esses meios a sociedade começou a opinar inclusive sobre a política. O uso do registro linguístico formal do atual presidente desencadeou muitas discussões sobre identidade e preconceito linguístico; nelas diferentes pontos de vista são revelados e é possível perceber que os papeis sociais têm se configurado no uso da língua bem como no reconhecimento, valorização ou desprestígio das variedades.

Palavras-chave: Preconceito linguístico. Internet. Meme. Política

\begin{abstract}
Bibliographical analyzes and readings of texts published on the Internet, which constitute a discussion about the use of the advanced oral language of President Michel Temer, led to the production of this article that aims to discuss how the internet, through so-called memes, has favored the reactions of Internet users in social networks in relation to the new Brazilian political scene. The discussions proposed here are fostered by theorists such as Britto (2002), Correa (2014) and Ferreira (2010) among others who argue about linguistic policies, identities and
\end{abstract}

\author{
* Mestrando do \\ Programa de \\ Pós-Graduação \\ em Estudos da \\ Linguagem da \\ Universidade \\ Estadual de Ponta \\ Grossa e professor de \\ Língua Portuguesa e \\ Espanhola na Escola \\ Pequeno Príncipe - \\ Educação Infantil e \\ Ensino Fundamental. \\ ** Doutora em \\ Estudos da \\ Linguagem pela \\ Universidade \\ Estadual de Londrina. \\ É Professora Adjunta \\ da Universidade \\ Estadual de Ponta \\ Grossa, atuando no \\ curso de Licenciatura \\ em Letras e \\ no Programa de \\ Pós-Graduação \\ em Estudos da \\ Linguagem.
}


ideologies, that often reveal values of truth or prestige. The study found that the internet has made it possible for the population to participate, to express opinions and debate on diverse topics, and memes are an effective tool for reaction and opinion in the pages of social networks. By these means society began to give its opinion on politics. The use of the formal linguistic register of the current president has triggered many discussions about linguistic identity and prejudice, in which different points of view are revealed and it is possible to perceive that social roles have been configured in the use of language as well as in the variety recognition, appreciation or discredit.

Keywords: Linguistic prejudice. Internet. Meme. Policy.

\section{Introdução}

É passado o tempo em que as opiniões ficavam guardadas para quem as formulava. A internet hoje permite ao usuário opinar e discutir sobre quaisquer assuntos. No âmbito político isso não é diferente. O objetivo deste artigo é discutir como a internet, por meio dos chamados memes, tem favorecido as reações de internautas em redes sociais em relação ao novo cenário político brasileiro. A saber, reações sobre a ultraformalidade usada na fala do atual Presidente da República e sobre outras manifestações e atitudes políticas. A troca de representantes do Governo, pós-impeachment, "revelou" à população uma variedade linguística "formal” e oportunizou diferentes pontos de vista sobre a língua e seu uso. Para alguns, finalmente a sociedade passou a ser representada por "alguém que conhece, respeita e sabe usar a língua”, para outros, no entanto, isso não significou absolutamente nada, ou até mesmo tornou-se motivo de piadas. Fato é que essas discussões, travadas em comentários e em postagens nas redes sociais, permitem uma ampla análise - e que fique claro: muito mais ampla do que a realizada neste estudo - do uso e das impressões bem como acerca do preconceito linguístico, que ainda parece reger as políticas linguísticas em todo o território nacional.

Os questionamentos que guiam essa pesquisa são: O uso da variedade culta da língua pelo presidente Michel Temer pode representar alguma ideologia, ou mesmo algum tipo de exclusão, ou preconceito linguístico? Como a população brasileira tem visto e reagido a essa nova "voz" da presidência? Que papel de importância a variedade culta da língua representa para a sociedade quando se trata da figura presidencial?

Para respondê-los, este artigo as discussões se encontram distribuídas da seguinte maneira: primeiramente faz-se um levantamento breve do referencial teórico que serviu de apoio para argumentar e fundamentar as discussões do texto; na segunda parte do artigo, apresenta-se a metodologia de estudo para as análises; no terceiro item do texto, a discussão versará sobre o papel da internet nas manifestações de ideologias através de um gênero chamado 
meme, e como essas manifestações se referem à nova realidade política brasileira; o quarto item discute um tema bastante polêmico, tratando dos valores e ideologias a respeito da língua e seu uso em diferentes variedades (coloquial e/ou formal) referentes à formalidade oral do presidente Michel Temer, estendendo-se ainda para as repercussões e impressões da mídia e da população quanto à postura do presidente; por fim, nas considerações finais, retomam-se os resultados das análises e discussões.

\section{Referencial teórico}

As argumentações presentes neste artigo apoiaram-se em estudos da área da Linguística e suas subáreas como é o caso das Políticas Linguísticas. Britto (2002) e Correa (2014) fundamentaram as discussões acerca da língua e seus usos, bem como as visões de língua que a sociedade retrata. Para tratar de aspectos como preconceito linguístico, identidades construídas através das manifestações linguísticas, situações de inclusão e exclusão também evidenciadas pelos usos da língua, o estudo de Ferreira (2010) é de fundamental importância. As discussões sobre usos da internet como espaço de debates, memes como meios de manifestações de ideologias, e políticas linguísticas e públicas, têm como respaldo os estudos realizados por Milroy (2011) e Souza (2013), entre tantos outros autores que permitiram ampliar as discussões que se seguem.

\section{Metodologia}

Este estudo está pautado em leituras, identificações e análises de diversos textos publicados em páginas da internet, e em que na maioria dos casos configuram mensagens de teor humorístico, crítico e até preconceituoso. As discussões propostas têm em vista a análise de como a internet, este meio tão democrático de disseminação de informação e debate, tem revelado os valores sociais e as reações da população em relação às falas do então presidente da República do Brasil, Michel Temer. Nesse sentido versará sobre as Políticas Linguísticas, políticas públicas, preconceitos linguísticos e as relações de poder imbricadas nos discursos tanto da massa, quanto da figura pública representada pelo presidente.

Os dados apresentados para análise, como comentários e sentenças reproduzidas, foram publicados em sites e redes sociais como Facebook, YouTube e mesmo em publicações diversas da internet. A publicação de comentários em postagens de vídeos ou artigos da internet pode facilmente ser excluída ou editada pelo usuário que a escreveu. Fato é que pelo fluxo de comentários que essas publicações geram resulta em grande dificuldade encontrá-las um tempo depois. Os nomes de usuários nem sempre retratam a identidade real do internauta, o que também dificulta a identificação de quem escreveu um ou outro comentário, portanto neste artigo nomes serão abstraídos. 


\section{A internet como meio de comunicação e debate}

A caminho da chamada inclusão digital, a internet propagou-se pelas mais diversas camadas sociais e trouxe para a sociedade os direitos de manifestação e divulgação de opiniões, antes entendido como tarefa dos meios de comunicação restritos como os jornais e revistas, ou programas de rádio e televisão. Sobre essa expansão, Kramsch (2014) declara que:

A internet e as formas eletrônicas de comunicação têm tirado espaço das formas convencionais e previsíveis de comunicação oferecidas pela literatura impressa, gramáticas e dicionários, e aberto um caminho para criatividade, agência e inovação, mas têm também aumentado a incerteza e a ambiguidade semiótica. Para resumir, elas têm mudado o nosso significado de comunicação, língua e cultura. (KRAMSCH, 2014, p. 10).

Nesses meios a informação se propaga rapidamente e se replica de maneira indiscriminada e incontrolável. Não obstante, a expansão permitiu à população, antes submetida e somente passiva no processo da comunicação, participar e opinar acerca dos mais diversos assuntos em voga no mundo. Assim, torna-se indispensável para o estudo aqui proposto associar ideias como comunicação, inclusão social e linguagem, tendo em vista que esta última representa um elemento essencial para a vida em sociedade e, conseguintemente, comunicação e inclusão fazem parte desse processo.

As linguagens e as comunicações evoluíram e mudaram ao longo dos tempos e essa evolução não pode ser desprendida de um fator primordial, esse processo se deu porque as sociedades evoluíram, porque as sociedades mudaram. (TEMER \& TONDATO, 2009, p. 76). Entretanto, ao discutir sobre o acesso que a população tem à manifestação midiática e como se dá esse acesso, Meili (2010) aponta que nem tudo foi sempre favorável nessa relação. A democracia da informação e da comunicação, no que se refere aos meios mais conhecidos, não é assim tão democrática, ou seja, a autora assegura que há sim uma forma de exclusão nos usos da linguagem midiática:

Não se pode esquecer que a Super-Mídia trabalhou e trabalha para o desenvolvimento e consolidação dos Estados Nacionais modernos, para unificar as pessoas através do sonho de crescimento e formar uma identidade moderna. O Rádio, a TV e a Imprensa foram instrumentos que se organizaram para a emissão unilateral da mensagem (um para todos ou o maior número possível). A maioria não fala, a maioria recebe, assiste, ouve; nada a impede de pensar, aceitar em partes totalmente ou negar, mas os elementos dados para essa escolha vêm de um só lado. É aí que está a exclusão: não se tem acesso irrestrito aos meios, nem mesmo restrito: eles afirmam-se unilateralmente. (MEILI, 2010, p. 38).

Nesse sentido a internet tem representado um diferencial, como muito bem fomentado pelo argumento de Kramsch (2014). Com seus ambientes 
virtuais, acesso facilitado, troca de informações simultâneas e suas infinitas possibilidades de interação, a internet parece criar o ambiente ideal para intermediar debates deliberativos e estimular o envolvimento do público. (SAMPAIO\& BARROS, 2011). E é justamente o “empoderamento” que a internet tem oferecido aos seus usuários, bem como suas consequências ou repercussões que se tomou como problematização para este artigo. As redes sociais, hoje tão disseminadas pelos usuários da internet, são um exemplo claro de como as pessoas tomaram a liberdade de opinar sobre assuntos das mais diversas naturezas, seja no âmbito público, político, artístico ou pessoal de maneira imediata e sem burocracias. Nessa nova realidade virtual, e como meio de resposta e propagação de uma ideia, destacam-se os chamados memes, que representam um fenômeno no mundo e nas comunicações via web. No próximo subitem se discute um breve conceito sobre eles.

\section{Os memes da internet}

Com o advento das redes sociais como o Facebook, Instagram, WhatsApp e Twitter - sem falar nas outras muitas -, a humanidade intensificou e dinamizou sua comunicação e pode, enfim, partilhar ecompartilhar suas opiniões, seus gostos e suas atividades em tempo real, com uma comunidade que extrapola os limites continentais. Não é difícil encontrar opiniões e dicas sobre as mais diversas coisas, desde um livro ou produto esportivo, até as mais elaboradas técnicas de maquiagem ou construção, como também é possível registrar debates em comentários de vídeos, postagens, etc. As formas e apresentações dos textos variam, vão de emojis, pequenos desenhos disponibilizados pelos aplicativos ou páginas que representam emoções ou reações, até textos argumentativos extensos. Entretanto, os memes que em especial têm tomado grande vulto nesse meio. Para tratar desse gênero, Recuero (2007) retoma os conceitos de Dawkins (1976):

O conceito de meme foi cunhado por Richard Dawkins, em seu livro "O Gene Egoísta”, publicado em 1976. A partir de uma abordagem evolucionista, Dawkins compara a evolução cultural com a evolução genética, onde o meme é o "gene” da cultura, que se perpetua através de seus replicadores, as pessoas. (RECUERO, 2007, p. 23).

Assim, a unidade que é esse gene se prolifera como uma mensagem compartilhada por milhões de pessoas e se replica instantaneamente. Os memes são passados adiante pela imitação, fenômeno oportunizado pelo maior potencial de criações de conteúdos e compartilhamento deles.

As opiniões expressas, os traços ideológicos, as crenças estão cada vez mais engendradas nas falas dos indivíduos que interagem cotidianamente em sites de relacionamento como o Facebook, o Twitter e em comentários a vídeos publicados no YouTube, através de postagens próprias, ou de 
replicação de conteúdos recebidos. É o jogo da adesão, ou mesmo adoção de ideias - na qual a dinâmica do "curtir” e do "compartilhar" ganha cada vez mais espaço. É uma subcultura dentro da cibercultura que cresce no ciberespaço em proporções tão aceleradas quanto à velocidade de transmissão de informações na internet. (SOUZA, 2013, p.128).

Como dito um pouco acima, o acesso quase ilimitado à informação oportunizado pela internet e a capacidade de opinião, oportunizada pelos campos destinados aos comentários, possibilitaram às pessoas opinarem acerca dos assuntos que bem desejarem. A população encontrou nos memes, essas imagens comuns com mensagens humorísticas ou críticas, uma útil ferramenta para reagir inclusive sobre um dos assuntos que mais geram discussões no mundo atual: a política.

\section{Os memes da política}

“O humor é um aspecto recorrente no noticiário, e no âmbito político.” (CHAGAS et al, 2017, p. 178). O cenário político nacional, em muitos momentos oportunizou a reação cômica - ou nem tanto - da população. Nos últimos anos o Brasil atravessa um período conturbado e os memes tornaram-se uma ferramenta bastante “eficaz” em transmitir o pensamento do eleitorado. Nesse sentido o meme não pode ser entendido como um gênero raso e desprovido de intencionalidades como alguns autores apontam. E é importante pensar essas questões, sempre voltadas à realidade social, pois conforme Halfeld (2013), o sentido, aqui tratando do humor presente nos memes, somente é estabelecido no interior dos contextos discursivos, assim carecendo de interação social. Ou seja, as piadas que recheiam milhares de memes espalhados pela internet sobre a política brasileira, por exemplo, não fariam sentido se não se tivesse ciência dos acontecimentos neste cenário. Por esse motivo, também, muitas piadas sobre política não surtem efeito senão no contexto nacional onde foram criadas.

Enfim, um pouco mais adiante neste texto, os efeitos das publicações de memes em páginas de redes sociais se farão mais ilustrados por exemplos da contemporânea situação política de postura, de práticas políticas e de poder do Governo, mesmo em suas reações a essas publicações.

\section{“Quem fala melhor: Temer, Dilma ou Lula?”: preconceito linguístico na internet}

A frase que abre esta seção, entre as aspas, foi escolhida propositalmente e intitula um texto publicado na internet pelo escritor Reinaldo Polito, em 17 de junho de 2016. No texto, o autor lista os oito últimos presidentes da República, elencando adjetivos referentes à oratória de todos eles. Termos como "elegante”, "bem preparado intelectualmente” são atribuídos, por 
exemplo, a Fernando Henrique Cardoso, presidente do Brasil de 1995 a 2002. Lula, presidente de 2003 a 2011, era “competente”, segundo o escritor, com seus discursos simples e ilustrações sobre churrasco e futebol, essa mesma característica vista de maneira negativa segundo outras fontes. O discurso de Polito muda, assumindo um tom quase agressivo, quando se trata de Dilma Rousseff, que exerceu o cargo de presidente de 2011 até seu afastamento em 2016. Dilma era “péssima oradora”, afirma Polito. No entanto quando se trata do atual presidente, Michel Temer, o discurso enaltece suas qualidades. Nas palavras do autor:

Temer chegou como um bálsamo com sua oratória. Formal, quase protocolar, cirúrgico nas ideias que defende. Não agride a gramática. Não perde a linha de raciocínio. Não se compromete com afirmações contraditórias. Ao contrário de Dilma, pensa antes de falar. É provavelmente um dos presidentes de comunicação mais elaborada que tivemos no país. (POLITO, 2016, on-line).

Claro que torna-se circunstancial ressaltar que a pretensão de Polito era fazer um levantamento a partir das competências oratórias dos presidentes, mas fica também evidente o papel superior atribuído ao mais competente conforme sua listinha, porque segundo ele, Temer é “perfeito” em seus discursos. Talvez fosse muito interessante pensar: em quais parâmetros se mediu essa atribuição? Pois segundo Ratier (2017) falar difícil não é falar bem.

\section{“Verbat volant, scripta manent”: a ultraformalidade de Temer}

Britto (2002, p.135) afirma que “as palavras não são neutras, a língua não é neutra.” Diante disso, pode-se pensar: o presidente Michel Temer, pela sua "formação jurídica”, - entre essas aspas, suas próprias palavras sempre escolheu as maneiras mais formais de se comunicar desde antes de sua posse como presidente. Por representar um contraste gritante em relação à sua antecessora, tomou vulto nos meios sociais pelo seu uso "respeitoso e carinhoso” da Língua Portuguesa, tão maltratada pelos presidentes Lula e Dilma. Na página do Facebook da Revista Veja, é possível encontrar um vídeo apresentado pelo jornalista Augusto Nunes, cuja descrição é a seguinte: “Na prova de português, Temer massacra Dilma e Lula”. É possível perceber a visão limitada apresentada pelo jornalista acerca do ensino de Língua Portuguesa, tido como um mero fomento das regras gramaticais. Sobre esse aspecto, o argumento apresentado por Correa (2014) permite compreender que:

[...] embora muitas vezes se reconheça uma visão heterogênea de língua, os estudos demonstram que na prática cotidiana, não só pedagógica, mas também social e ideológica, figura-se preponderantemente a visão homogênea, 
abalizada pela norma padrão, sem considerar as especificidades da norma culta e das variedades linguísticas. (CORREA, 2014, p. 19).

A idolatria à variedade padrão é evidenciada pelo jornalista em seus comentários irônicos que buscam, de maneira teatralmente agressiva, desprestigiar a fala de Dilma Rousseff e Luiz Inácio Lula da Silva. Para encerrar a argumentação de Augusto Nunes, ele finaliza seu comentário dizendo que, finalmente, “depois de treze anos o país voltou a ser governado por alguém que sabe falar português”. Sobre a ideia de uso correto da língua, Britto (2002) afirma:

A ideia básica que predomina nas sociedades de escrita, como é o caso da sociedade ocidental, é que existe uma forma correta de falar - a norma culta ou língua formal ou ainda língua padrão, entre outros nomes - e que conhecer e saber usar essa forma é importante para poder participar ativamente da sociedade. (BRITTO, 2002, p. 145).

O mesmo autor ainda defende que:

Pode-se argumentar que a norma culta, do jeito que é preconizada nas gramáticas, é apenas uma idealização, que funciona como uma espécie de lei, determinando usos orais e escritos e servindo de referência para a correção das formas linguísticas. De fato, não é falada por quase ninguém, e mesmo as pessoas instruídas e de boa condição social erram com relação à gramática. Sua utilidade estaria em estabelecer um padrão que garantisse a unidade linguística nacional e os usos formais, públicos da língua. (BRITTO, 2002, p. 147).

Para o Doutor em Educação Rodrigo Ratier, o presidente Michel Temer escolheu essas formas para se comunicar no intuito claro de se diferenciar de seus antecessores, utilizando-se do que ele chama de uma norma cultuada da língua, ou seja, o "português correto”, que não passa de um mito.

Quando Temer, em sete de dezembro de 2015, enviou a então Presidente da República Dilma Rousseff sua carta pessoal de lamentações, por ser um vice presidente decorativo ${ }^{1}$ - com o título em Latim que abre esta seção qual, em uma livre tradução, significa algo como: "as palavras voam, a escrita permanece”-, não o fez senão pelos meios e recursos linguísticos mais formais possíveis. Isso indica uma clara utilização do código linguístico como instrumento de poder, talvez reflexo de sua formação acadêmica, naturalmenteinfluente em sua própria identidade.

[...] todo movimento de identificação consiste num gesto de uma instância tal representar-se como e, assim, identificar-se com. Esse gesto consiste sempre num ato de inclusão e exclusão ao mesmo tempo, uma vez que opera uma redução que tornará possível o sentimento de identidade. [...] Em outras palavras, todo movimento de identificação consiste na enunciação,
${ }^{1}$ É possível ler a carta com as onze lamenta ções de Michel Temer na íntegra, no endereço: https://brasi 1.elpais.com/brasil $/ 20$ 15/12/08/politica/144 9575635 971456.html 
na proposição, na reiteração de determinados traços e, consequentemente, na exclusão de outros. Esse gesto de inclusão e exclusão estabelece um espaço simbólico constitutivo de um sujeito cujas formas de subjetivação vão ser pautadas pelo reconhecimento de uma suposta singularidade. (FERREIRA, 2010, p. 20).

\section{As mesóclises de Temer: um instrumento de exclusão?}

Outra característica da fala do presidente Michel Temer foi destaque de muitas matérias e comentários nas mídias. O uso de mesóclises em seus discursos repercutiu como uma singularidade. Logo em seu discurso, em que empossou novos ministros, Temer disse: "Nenhuma dessas reformas alterará os direitos adquiridos pelos cidadãos brasileiros. Quando menos fosse sê-lo-ia pela minha formação democrática e pela minha formação jurídica.” O uso da mesóclise não está de maneira alguma equivocado, no entanto deixa claro que o presidente se queria fazer notar pelo uso quase que exageradamente formal da língua, o que evidentemente lhe rendeu alguns aplausos e muita repercussão. A mesóclise, segundo o dicionário Houaiss, é a colocação do pronome oblíquo átono entre o radical e a desinência das formas verbais do futuro do presente e do futuro do pretérito. Guimarães (1996), por sua vez, traz um conceito um tanto mais complexo sobre a mesóclise.

Ela só se dá nas formas de futuro do presente e futuro do pretérito. Tem-se amar-te-ei, amar-te-ia. Ou seja, a mesóclise é uma colocação que mostra que o futuro do Português vem da junção de dois verbos (mesmo que já tenha havido uma completa fusão do verbo e do auxiliar habere, inclusive porque o acento se dá sobre a flexão temporal que restou de habeo, habeas, etc, mostrando que não se tem mais duas palavras). No funcionamento da frase, o futuro mostra o passado desta forma operando no presente. Em outras palavras: estamos diante de uma memória da palavra relativamente às enunciações que formaram historicamente o futuro. (GUIMARÃES, 1996, p. 29).

Tomanin (2009) aponta que, apesar de muitos estudos já anunciarem sua queda - o que inclusive também afirma o próprio Guimarães no texto acima citado -, a mesóclise ainda resiste no Português Brasileiro. A autora propõe uma redefinição para essa colocação que talvez não seja conveniente debater aqui, haja vista que, para tratar do tema, seria necessária uma exaustiva descrição de regras e usos gramaticais que não caberiam no corpo deste artigo.

Retomando as argumentações de Ratier (2017), o autor defende que o uso das mesóclises pelo presidente denota um "instrumento de exclusão" justamente por se tratar de um recurso em desuso na língua. Segundo o autor, Temer faz uso da norma cultuada da língua, ou seja, de uma língua que é apenas um ideal de perfeição. Entretanto, em outros comentários da 
internet, travam-se discussões em que se afirma que, em verdade, o discurso do presidente oscila quanto ao grau de formalidade.

Como dito anteriormente, a formação jurídica de Temer, muito possivelmente, é o que influencia em sua oralidade, mas é preciso esclarecer que, de maneira alguma, sua capacidade de argumentação é alvo de questionamentos. "Saber argumentar não perdeu em absoluto em relevância. É o que fazem os estadistas, os políticos, os advogados, os publicitários, os vendedores." (OLIVEIRA, 2007, p. 85). Assim, percebe-se que o que chama a atenção de um grande número de pessoas não é o fato de Temer possuir uma boa técnica argumentativa, ou retórica, mas sim o seu uso "adequado" da língua padrão. É possível perceber, em muitos depoimentos e comentários escritos na internet, que esse culto à norma padrão da língua ou norma curta, como a chama Faraco (2008), levanta manifestações ideológicas, e se faz ainda muito presente no ideal de grande parte das pessoas. Nesse ínterim torna-se uma tarefa fácil perceber as manifestações de preconceito linguístico, imbricadas nos discursos e atitudes do senso comum.

Entretanto, embora as atitudes de senso comum sejam ideologicamente carregadas, aqueles que as sustentam não as veem de modo nenhum como tais: eles acreditam que seus juízos desfavoráveis sobre pessoas que usam a língua "incorretamente” são juízos puramente linguísticos sancionados por autoridades sobre língua, e essa crença é, em parte, ela mesma, uma consequência da padronização. As pessoas não associam necessariamente esses juízos com preconceito ou discriminação em termos de raça ou classe social: elas acreditam que, sejam quais forem as características sociais dos falantes, estes simplesmente usaram a língua de uma modo errado e que existe para eles a possibilidade de aprender a falar corretamente. Se não o fizerem, é por culpa própria deles, como indivíduos, seja qual for sua raça, cor, credo ou classe; existe uma abundância de modelos do "bom" falar para eles. (MILROY, 2011, p. 59).

Dentre as muitas manifestações escritas nos comentários dos vídeos e postagens anteriormente citados, é possível encontrar frases como:

- Um belo português é o minimo que podemos esperar de um presidente da república. Mas nem o minimo o lularapio e A guerrilheira Rousseff sabiam..quanto mais presidir um país??! Reflita.

- Lula e Dilma assassinam o idioma pátrio, enquanto Michel Temer o respeita.

- Ate que enfim um líder um presidente que se pronuncia como se deve um presidente de uma republica!

- Este é graduado. ${ }^{2}$

- Esses textos demonstram ideologias que refletem o culto à norma padrão da língua e é ainda possível perceber que, em alguns casos, o domínio ou uso da variedade cultuada atribui ao falante, nesse caso o presidente, um caráter digno de admiração e aos que não o dominam são atribuídos

\footnotetext{
2 Para manter a fidelidade dos exemplos selecionados, os comentários foram transcritos como originalmente postados em diferentes páginas, como YouTube Facebook e até mesmo em comentários ao artigo publicado por Reinaldo Polito e ao vídeo de Augusto Nunes,. De forma alguma refletem a opinião do autor deste artigo nem enaltece as ideologias neles presentes.
} 
valores inferiores como a incompetência, mesmo em outras áreas ou habilidades de atuação e posição/condição social. Diante dessas constatações, vale ressaltar a afirmação de Britto (2002) que assevera que "a língua é um dos lugares em que a ideologia é mascarada, é despercebida e, portanto, é violenta.” (2002, p. 137). E nesse caso é evidente que essas ideologias nem sempre estão tão mascaradas, nem sempre são despercebidas, no entanto, são seguramente violentas.

\section{“Agora não pode mais fazer meme - Aguiri ni pidi mis fizir mimi”": a resposta do governo sobre os memes}

Os discursos formais e o uso de vocabulário rebuscado, assim como algumas declarações polêmicas, proferidos pelo Presidente da República Michel Temer rendeu à internet material para muitas discussões e, claro, muitos memes. Como mencionado anteriormente, os memes são praticamente um viral na rede e representam a manifestação rápida e muitas vezes satírica sobre qualquer coisa. Assim aconteceu desde os primeiros sinais de posse do novo presidente. Entretanto essas reações da população não agradaram muito os representantes do Governo. Segundo matérias de vários jornais e blogs, as páginas responsáveis por criar memes foram notificadas sobre o "uso indevido" da imagem do presidente em fotografias oficiais. Essa atitude do Governo, que por sinal enfrenta no contexto atual uma grave crise política, apenas fez crescer sua impopularidade e foi entendida como um ato político autoritário. A nota do Governo enviada aos administradores das páginas citava a Lei de Direitos Autorais (Lei 9610/98), na tentativa de insinuar o direito do presidente de reclamar essas imagens e de seus produtores serem identificados. Entretanto, como afirma Avedaño (2017), autor da reportagem no portal eletrônico do jornal El País, isso é impossível por causa da maneira como se produzem os memes.

O que realmente chamou a atenção da imprensa e dos usuários da internet foi a atitude autoritária, e quase ameaçadora, do Governo frente a essas manifestações de cunho popular. O que por ironia pareceu surtir o efeito inverso, já que as manifestações de repúdio tomaram grandes proporções e renderam outros tantos memes. Um deles retrata o presidente em dois momentos proferindo a frase que abre este subitem, deixando claro o teor satírico desse tipo de publicação. Felizmente a sociedade tem usado esse pequeno e simples método de reação para manifestar suas ideologias, suas crenças e suas opiniões, outrora caladas pela impossibilidade de se fazerem ouvir.

\section{Considerações finais}

As manifestações em redes sociais da internet sobre a fala ultraformal do presidente Michel Temer demonstram uma nítida divisão de opiniões acerca do uso oral da língua e em muitos casos nota-se que o preconceito

\author{
${ }^{3}$ Transcrição de \\ meme feito com \\ imagem do presidente \\ da República Michel \\ Temer, disponível na \\ internet, encontrado \\ no site: https:// \\ blogclaraboia. \\ blogspot.com.
}


linguístico ainda dita as regras de uso da língua. Segundo Bagno (2007) é comum encontrar pessoas que ainda atribuam à norma padrão da língua um valor de instrumento de ascensão social. Esse preconceito fica evidente através das postagens que desprestigiam a fala de Dilma ou Lula e enaltecem a de Temer apenas por considerarem que o atual presidente respeita ou "sabe português”. Verdade seja dita, as opiniões se dividem, e uma grande porção de pessoas se demonstra conhecedora das variedades e do caráter vivo, dinâmico e heterogêneo da língua. Reconhecendo inclusive as supostas intenções do presidente em se fazer notar pelo seu uso polido do idioma, destacando-se e diferenciando-se, assim, de seus antecessores. Como resposta a uma das perguntas iniciais deste texto, retomam-se as palavras de Britto (2002): nada na língua é neutro... a língua é um dos lugares em que a ideologia é mascarada, é despercebida e, portanto, é violenta.” Quando o presidente escolhe minuciosamente suas palavras, pronunciando cada uma delas com cuidado, e deleita-se com os aplausos, ele o faz de caso propositalmente, e quando, numa atitude autoritária e repressiva, tenta proibir a mídia popular de manifestar o desagrado da população, o faz para demonstrar quem tem mais poder. Com sorte, a internet contará, enquanto precisar, com muitos memes e comentários e não se extinguirá a língua de ninguém.

\section{Referências}

AVEDAÑO, Tom C. Fora meme? Como o Governo Temer virou inimigo da indústria das piadas na Internet. São Paulo, 2017. Disponível em: https://brasil.elpais.com/brasil/2017/05/27/ciencia/1495899503_382776. html Acesso em: jul. 2017.

BAGNO, Marcos. Preconceito Linguístico: o que é, como se faz. 49. ed. São Paulo: Loyola, 2007.

BRITTO, Percival Leme. Língua e ideologia: a reprodução do preconceito. In: BAGNO, Marcos. (Org.). Linguística da Norma. São Paulo: Loyola, 2002. v. 1, p. 178-184.

CHAGAS, Viktor, FREIRE, Fernanda Alcântara, RIOS, Daniel, MAGALHÃES, Dandara. A política dos memes e os memes da política: proposta metodológica de análise de conteúdo de memes dos debates eleitorais de 2014. Intexto, Porto Alegre, UFRGS, n. 38, p. 173-196, jan./ abr. 2017.

CORREA, Djane Antonucci. Práticas linguísticas e ensino de língua: variáveis políticas. In: CORREA, Djane Antonucci. Política Linguística e ensino de língua. Campinas: Pontes, 2014.

FARACO, Carlos Alberto. Norma culta brasileira: desatando alguns nós. São Paulo: Parábola Editorial, 2008. 
FERREIRA, Ruberval. Identidade, exclusão e consumo no contemporâneo: a diferença na vitrine.In: FREITAS, Alice Cunha de. (Org.) Linguagem e Exclusão. Uberlândia: EDUFU, 2010.

GUIMARÃES, Eduardo. Enunciação, língua, memória. IRevista da ANPOLL, n. 2, p. 27-33, 1996. Disponível em: <https://revistadaanpoll. emnuvens.com.br/revista/article/viewFile/238/251> Acesso em: dez. 2018.

HALFELD, Paula. A produção do humor na rede social Facebook. Revista Soletras, 26, 2013.

KRAMSCH, Claire. Por que os professores de língua estrangeira precisam ter uma perspectiva multilíngue e o que isso significa para sua prática de ensino. In: CORREA, Djane Antonucci (Org.). Política Linguística e ensino de língua. Campinas: Pontes, 2014.

MEILI, Angela Maria. A exclusão midiática enquanto silenciamento generalizado. In: FREITAS, Alice Cunha de. (Org.) Linguagem e Exclusão. Uberlândia: EDUFU, 2010.

MILROY, James. Ideologias linguísticas e as consequências da padronização. In: LAGARES, Xoan; BAGNO, Marcos. Políticas da norma e conflitos linguísticos. São Paulo: Parábola Editorial, 2011. p. 49-85.

NUNES, Augusto. Na prova de português, Temer massacra Dilma e Lula. Veja.com (Vídeo) 13 de maio de 2016. Disponível em: <https:// www.facebook.com/Veja/videos/10153958638415617/> Acesso em: jul. 2017.

OLIVEIRA, Gilvan Müller de. A “virada político-linguística” e a relevância social da linguística e dos linguistas. In: CORREA, Djane Antonucci (Org,). A relevência social da linguística: linguagem, teoria e ensino. São Paulo: Parábola Editorial; Ponta Grossa, PR: UEPG, 2007.

POLITO, Reinaldo. Quem fala melhor: Temer, Dilma ou Lula? 15 de maio de 2016. Disponível em: <https://economia.uol.com.br/blogs-e-colunas/ coluna/reinaldo-polito/2016/05/17/diferencas-na-comunicacao-de-luladilma-e-temer.htm> Acesso em: jul. 2017.

RATIER, Rodrigo. A mesóclise de Temer é um instrumento de exclusão. 20 de Junho 2017. Disponível em: <https:/novaescola.org.br/conteudo/5026/ a-mesoclise-de-temer-e-um-instrumento-de-exclusao>. Acesso em: jul. 2017.

RECUERO, Raquel da Cunha. Memes em weblogs: proposta de uma taxonomia. Revista FAMECOS, Porto Alegre, n. 32, p. 23-31, abr. 2007. Disponívelem<http://www.redalyc.org/html/4955/495550188006>Acesso em: jul. 2017. 
SAMPAIO, R. C.; BARROS, C. T. G. Internet como esfera pública? Análise de usos e repercussões reais das discussões virtuais. Estudos em Comunicação, n. 9, 161-183, maio 2011.

SOUZA, Carlos Fabiano de. Memes: formações discursivas que ecoam no ciberespaço. Vértices, Campos dos Goytacazes/ RJ, v.15, n. 1, p. 127-148, jan./abr. 2013.

TEMER, A. C. R. P; TONDATO, M. P. Mídia e cidadania: uma relação na perspectiva histórica. Inter-Ação: Rev. Fac. Educ. EFG, v. 34, n.1, p. 7588, jan/jun. 2009.

TOMANIN, Cassia Regina. A cristalização da nova modalidade de mesóclise no português brasileiro. 2009. 153 f. Tese (Doutorado em Letras) - Universidade Estadual Paulista, Faculdade de Ciências e Letras de Araraquara, 2009. Disponível em: <http://hdl.handle.net/11449/106225>. Acesso em: jul. 2017.

Recebido em julho/2018.

Aceito em dezembro/2018. 